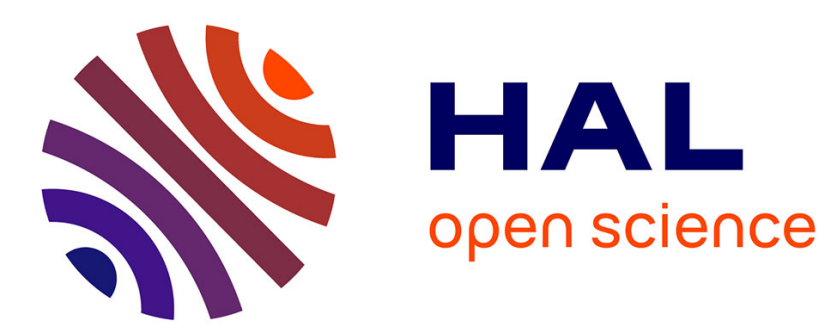

\title{
Rhine flood deposits recorded in the Gallo-Roman site of Oedenburg (Haut-Rhin, France).
}

Vincent Ollive, Christophe Petit, Jean-Pierre Garcia, Michel Reddé

\section{To cite this version:}

Vincent Ollive, Christophe Petit, Jean-Pierre Garcia, Michel Reddé. Rhine flood deposits recorded in the Gallo-Roman site of Oedenburg (Haut-Rhin, France).. Quaternary International, 2006, 150, pp.28-40. 10.1016/j.quaint.2006.01.006 . hal-00206188

\section{HAL Id: hal-00206188 \\ https://hal.science/hal-00206188}

Submitted on 11 May 2020

HAL is a multi-disciplinary open access archive for the deposit and dissemination of scientific research documents, whether they are published or not. The documents may come from teaching and research institutions in France or abroad, or from public or private research centers.
L'archive ouverte pluridisciplinaire HAL, est destinée au dépôt et à la diffusion de documents scientifiques de niveau recherche, publiés ou non, émanant des établissements d'enseignement et de recherche français ou étrangers, des laboratoires publics ou privés. 


\title{
Rhine flood deposits recorded in the Gallo-Roman site of Oedenburg (Haut-Rhin, France)
}

\author{
Vincent Ollive $^{\mathrm{a}, \mathrm{b}, *}$, Christophe Petit ${ }^{\mathrm{a}, \mathrm{c}}$, Jean-Pierre Garcia ${ }^{\mathrm{a}, \mathrm{b}}$, Michel Reddé \\ ${ }^{a}$ Université de Bourgogne, UFR Sciences de la Terre, 6 Bd Gabriel, 21000 Dijon, France \\ ${ }^{\mathrm{b}} U M R$ CNRS 5561 'Biogéosciences' \\ ${ }^{\mathrm{C}} U M R$ CNRS 5594 'Archéologie, cultures et sociétés' \\ ${ }^{\mathrm{d}}$ Ecole Pratique des Hautes Etudes, Paris
}

Available online 18 April 2006

\begin{abstract}
From the first to the fourth century AD, the Gallo-Roman town of Oedenburg developed in the alluvial landscape of the southern Upper Rhine Graben. Throughout this period, the landscape mosaic, composed of palaeochannels, stable palaeoislands and river terraces, continued to evolve. A district of this town, situated on a lateral Rhine channel system, was archaeologically excavated. Largescale excavation and cross-section analysis provide evidence of changing fluvial conditions during the period under study. At about AD 20 or earlier, this lateral part of the floodplain, affected by very fine sedimentation, was occupied by moribund marshy palaeochannels. When the first Gallo-Roman settlers occupied the site, they filled parts of the channels with woven brushwood in order to create an efficient circulation surface. The sedimentary infill of this palaeochannel records four different flood deposits interlayered with dated anthropogenic units (pavements, road embankments, and other structures). Archaeological analysis and dendrochronological dating indicate that these four flooding events occurred during a short time period between AD 20 and AD 145/146. These geoarchaeological observations focus on floods that do not seem to have significantly affected human occupation in this part of the Rhine floodplain. These results are set in the broader context of the Rhine catchment and the Alps.
\end{abstract}

\section{Introduction}

The present study aims to develop the understanding of past flooding events, riverine palaeoenvironment and hydrodynamic changes, and their relationship to archaeological occupation. Knowledge of these factors is necessary to estimate human influence on the drainage area and also to detect and assess climatic changes during the Upper Holocene (historic) times. Moreover, long-recurring catastrophic flooding events may be recorded during human history and it is useful to document how societies have been affected by such environmental stresses. Riverine archaeological sites are very appropriate objects for that purpose because they often provide a record of alluvial sedimentation and a well-defined chronology (Brown, 1997).

The present geoarchaeological study focuses on the sedimentary record of the Oedenburg Gallo-Roman site, in

*Corresponding author.

E-mail address: vincent.ollive@u-bourgogne.fr (V. Ollive). the floodplain of the southern Upper Rhine River (Fig. 1). This area has been influenced by Rhine floods for several hundred years, as demonstrated by the village of Kunheim, situated just $1 \mathrm{~km}$ from the archaeological site, which was close to the river in 1705 (Fig. 2), destroyed by floods in 1763 , and then rebuilt further up the terrace.

\section{Geomorphological context and study area}

\subsection{Rhine floodplain}

The Rhine is one of the largest rivers in Europe, with a total length of $1320 \mathrm{~km}$ and a catchment area of about $185,000 \mathrm{~km}^{2}$. The Upper Rhine Graben is situated between the plutonic and sedimentary Vosges and the Black Forest. Since the Oligocene, more than $1300 \mathrm{~m}$ of sediments have been deposited in this subsiding area (Blanalt et al., 1974; Théobald et al., 1978). In this graben zone, the Oedenburg Gallo-Roman site (Haut-Rhin) is located at the latitude of the Kaiserstuhl Volcano, at about $188 \mathrm{~m}$ above sea level 


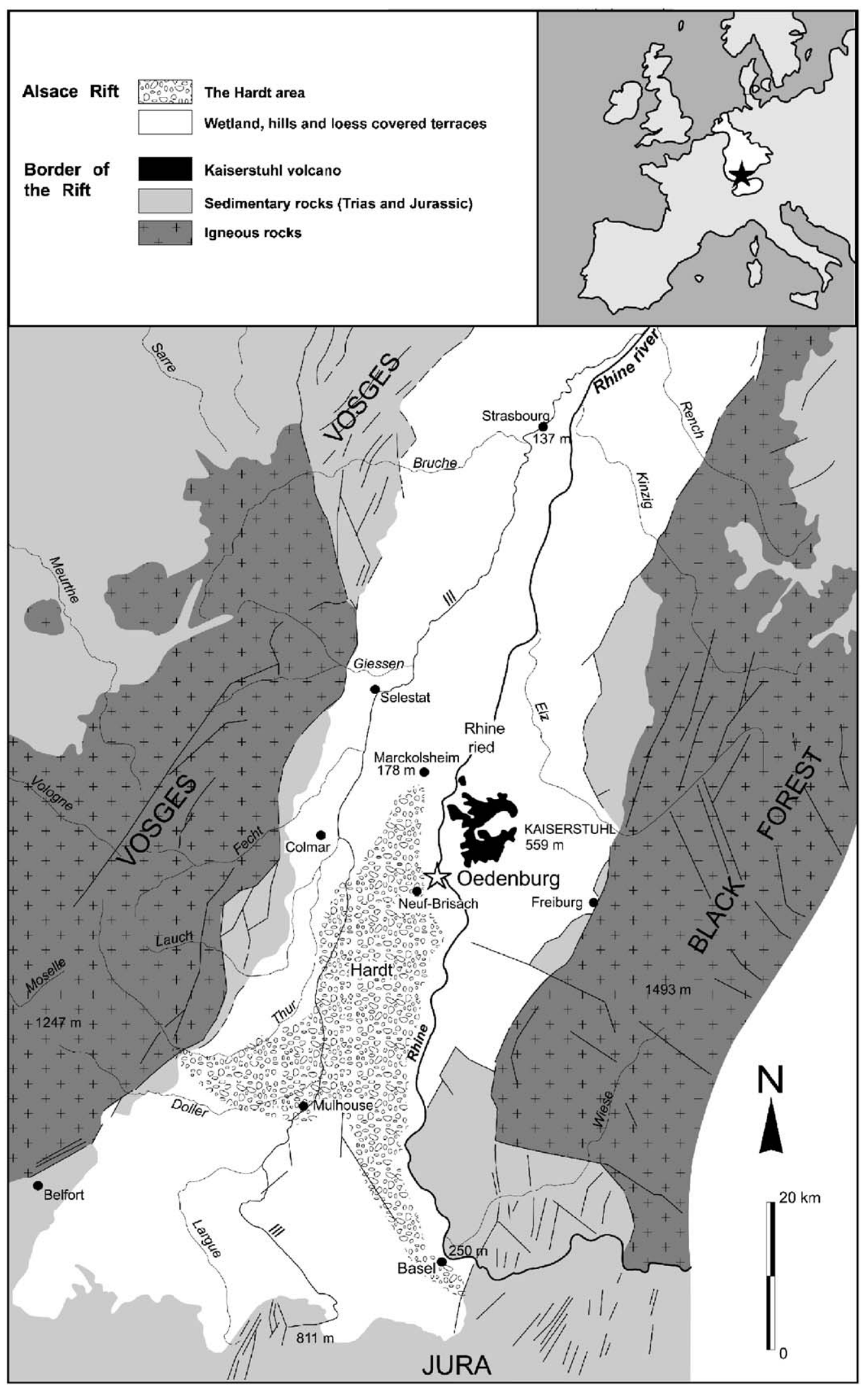

Fig. 1. Simplified geological map of the floodplain of the River Rhine, showing the location of the Oedenburg Gallo-Roman site.

(ASL) (from 185.4 to $192.0 \mathrm{~m}$ ASL). Two main rivers drain the Alsace floodplain: the Ill and the Rhine. These two rivers run northward and are continuously separated, in the reaches from Basel (250m ASL) to Marckolsheim (178 m ASL), by a Weichselian alluvial fan of Alpine origin (Fig. 1). To the east, the Rhine River runs northward from 


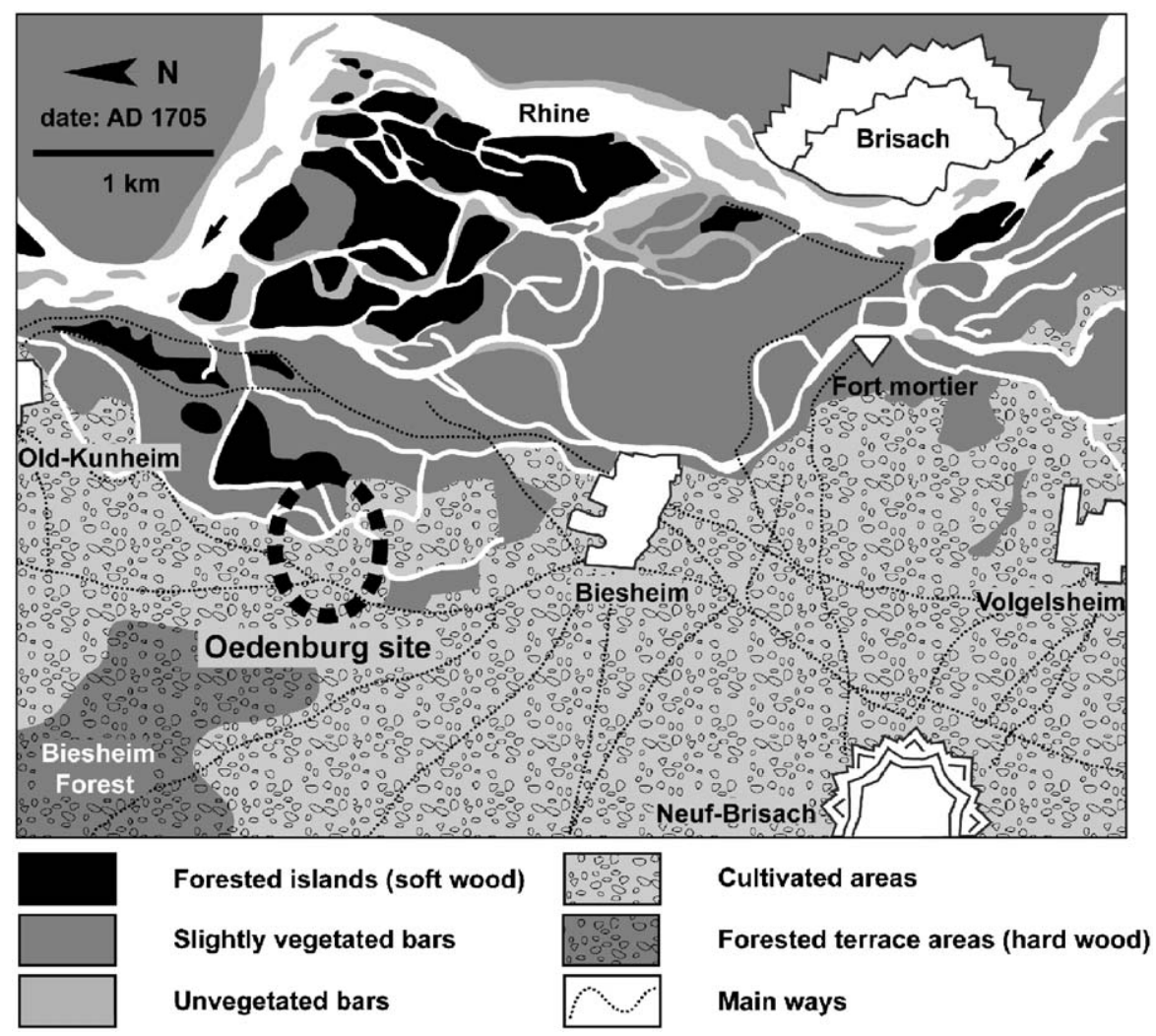

Fig. 2. Map of the Rhine floodplain in the Oedenburg site area during the 18th century, showing the succession of main alluvial landscapes resulting in different vegetation covers. After a 1705 map of the Neuf-Brisach area (Haut-Rhin). Note the site of "Old-Kunheim" located near the main active channels of the River Rhine.

the Alps and the Swiss molassic plain. To the west, the Ill River, the main Rhine tributary in Alsace, has a catchment area of $9800 \mathrm{~km}^{2}$, extending from the northern Jura chain. In this part of its catchment area, the Rhine River exhibits a braided style, owing to bar migrations between channels (Church, 1978; Schumm, 1981; Miall, 1996). This is principally due to the high mean slope value of the valley of about $0.87 \%$ (Schäfer, 1973). Consequently, a sizeable discharge has resulted in the formation of gravel bars supplied by the Alpine massif, the Swiss plain and the Jura. This morphology and most of the sediments of the Rhine floodplain are largely inherited from Plio-Quaternary history (Mäckel et al., 2002, 2003).

The landscape of this floodplain can be subdivided into two zones: the "Hardt" and the "Ried" depending on altitude, soil type and vegetation cover (Striedter, 1988; Carbeiner, 1997; Sell et al., 1998). The "Hardt" area represents the Weichselian alluvial fan (lower terrace) of the Rhine River, which has built up between the Ill and the Rhine, and now rises several metres above both (Blanalt et al., 1974; Théobald et al., 1978). It shows a relatively intense soil formation resulting in calcretes (also known as "Rheinweiss") and clay-rich soils. The "Rieds" are wet areas which are frequently inundated Holocene palaeochannels, mainly composed of fine sand or organic-rich sediments (fluviosols) (Baize et al., 1995).

\subsection{Study area}

The inspection of ancient maps allowed the former river pattern, channel abandonment and evolutive alluvial vegetation to be interpreted (Thorne et al., 1993). Many authors have demonstrated the close relationship between alluvial vegetation type, vegetation growth and timing of bar surface exposure between high stages (Williams and Rust, 1969; Bridge et al., 1986; Klein et al., 1992; Bridge, 2004). Thus, flood vulnerability may be documented, before the 19th century engineering works on the Rhine that changed the fluvial environment (Tulla, 1825, 1827; Eisenmenger, 1907; Lefoulon, 1959; Marchal and Delmas, 1959; Decoville-Faller, 1961; Tricart and Bravard, 1991). The study area $\left(2 \mathrm{~km}^{2}\right)$ is situated on both "Hardt" and "Ried" zones, as shown in Fig. 2. At the beginning of the 18th century (Fig. 2), the landscape in the vicinity of the Oedenburg site may be defined as a mosaic, subdivided into four areas, identified in relation to the type of vegetation. The active braided stream is recognised by unvegetated bars (transient state), while higher, softwood-forested islands form the second, stable area. A slightly vegetated wet grassland (e.g. Carex sp., Impatiens glandulifera, and Phalaris arundinace) with a small population of trees and shrubs (e.g. Salix sp., Cornus sanguinea, and Viburnum lantana) corresponds to the frequently inundated plain. The Oedenburg site is mainly located in this third part of 
the landscape and extends to the gravel terrace ("Hardt") where the hardwood forest and cultivated areas developed. The course of the main road which nowadays connects Biesheim with Oedenburg has followed the eastern border of the terrace since Roman times.

\subsection{Landscape and human analysis}

This alluvial landscape was analysed using aerial photographs and microtopography in order to replace the human settlement in its palaeogeographic setting. The inherited morphological structures of the ancient alluvial environment can be identified through maize growth anomalies due to changes in soil moisture and texture properties (Fig. 3). Several orthorectifications were performed on aerial photographs in order to characterise the exact extent of both humid and dry structures. The wetter, lower zones are interpreted as palaeochannels or anthropogenic excavated structures, such as ditches, filled with fine sediment. The drier zones correspond to alluvial landforms such as palaeobars and terraces, but also to anthropogenic structures such as Roman roads and walls.
The Oedenburg site developed on three distinct zones in this part of the alluvial landscape (Petit et al., 2006; Reddé et al., 2005). Zone A is situated on the eastern side. It is a wide, relatively dry zone ( $187.5 \mathrm{~m}$ ASL) showing several northward-oriented minor palaeochannels (10-20 m wide). It is interpreted as an ancient bar or island with superimposed cross-bar channels. In this part of the alluvial plain, ditches limiting a first-century Roman military camp were observed during excavation studies (Fig. 3A). Zone B is limited on its western side by the alluvial terrace, and comprises several islands and minor braided palaeochannels ( $50 \mathrm{~m}$ wide), and two larger meander-like palaeochannels of about $100 \mathrm{~m}$ in width. The modern canal cuts across these palaeochannels. The Roman archaeological site under study was built on the main island of Zone B, which measures approximately $200 \mathrm{~m} \times 300 \mathrm{~m}$ (Fig. 3B). In Fig. 3, a NE-SW-oriented Roman road can be observed, which connects the site to the alluvial terrace. To the west, Zone $\mathrm{C}$ represents the highest part of the study area (189-192 m ASL) and exhibits several N-S-oriented minor palaeochannels. The road between Biesheim and Kunheim runs along this terrace. Around this highest point of the

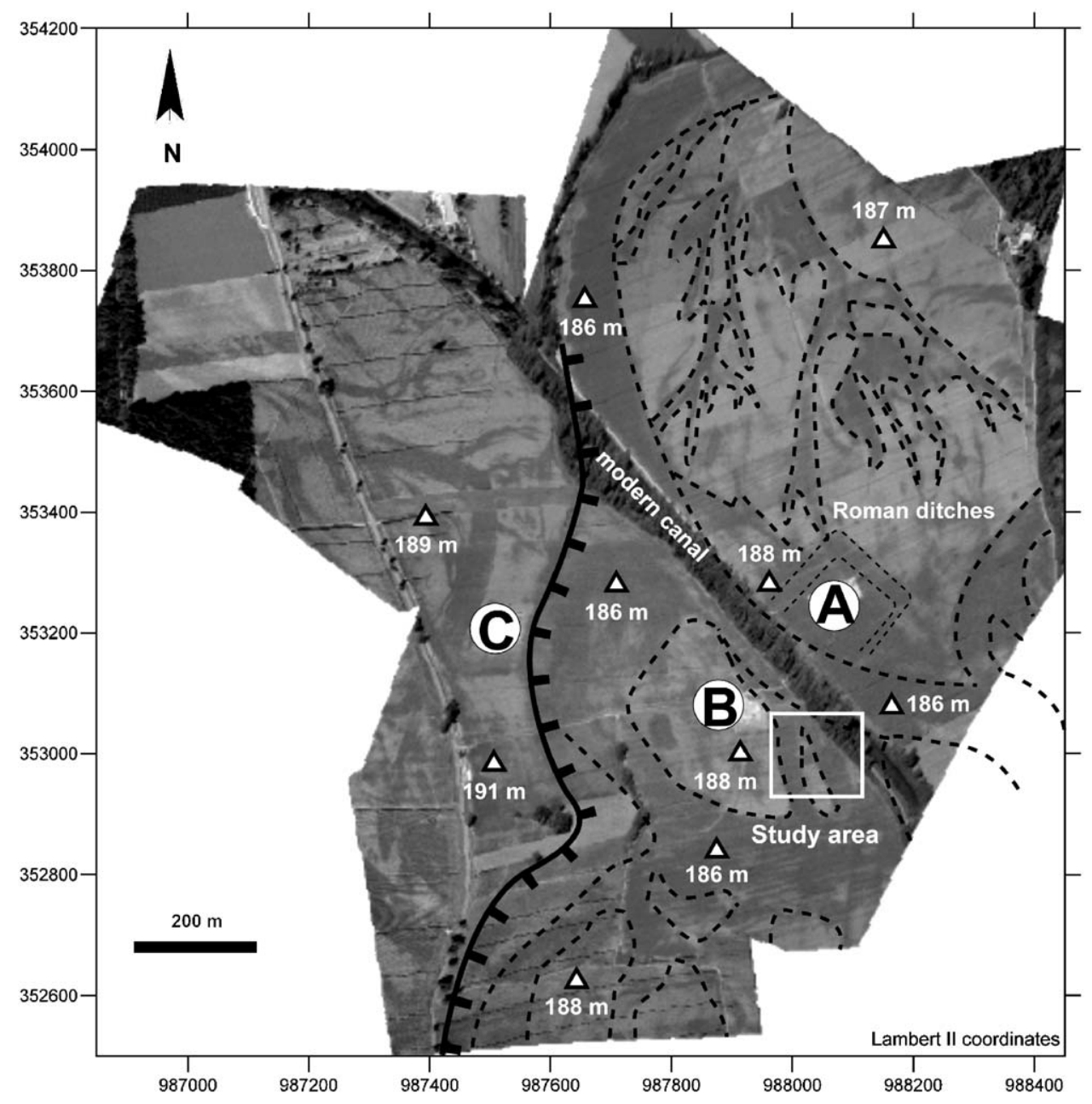

Fig. 3. Mosaic of orthorectified aerial photographs of the study area that allows the exact positioning of palaeochannels and palaeobars/islands: (A) 1st century Roman military camp; (B) main part of the 1st-3rd century Roman town; and (C) main part of the 4th century Roman town. Original photographs were taken by O. Brasch in 1999 (unpublished). Spatial coordinates are Lambert II extended. 
landscape, the major part of the 4th century settlement developed, around a military fortress (Fig. 3C).

\subsection{Chronology}

The archaeological site of Oedenburg is located in the Rhine floodplain. It was dedicated to civilian activities (1st-4th century AD) and to two different military settlements (1st and 4th century AD) (Zehner, 1998; Nuber et al., 2002; Petit et al., 2005; Reddé et al., in press). Thus, the excavated area shows a continuous period of occupation, encompassing the first four centuries of the Roman Period in Alsace. The studied area is located in Zone B, on the concave bank of a major meandering palaeochannel, shown in Fig. 3. This palaeogeographical setting allows us to describe the evolution of the landscape from the first century onwards (a civilian settlement associated to the military camp), up to the third century (the end of urban district development).

An area of approximately $4000 \mathrm{~m}^{2}$ (Fig. 3: Zone B and Fig. 4) was excavated in order to study this district of the Roman town. Two small, more or less linear palaeochannels were clearly identified by aerial photograph analysis and microtopographic surveys. They are separated by a longitudinal, stable gravelly island. The eastern channel is oriented to the north-west, while the western one is oriented north-eastward. Human settlement in this confluence zone may be subdivided into three major phases (Fig. 4). Phase 1 of the settlement, which is recorded as wood-rich layers and woody structures (building 1), can be found all over the surface of the excavated site and in the two marshy palaeochannels. These anthropogenic, woven brushwood deposits are widespread and formed a layer of brushwood matting, used to consolidate these Early GalloRoman channels. In this part of the site, Phase 1 is dated by dendrochronology to AD 20. Phase 2 corresponds to the expansion of Roman urbanisation. A road system, with two streets built across the palaeochannels, developed at about the same time. Attested by dendrochronological dating, the first, associated to building 1 (North-South Way, Fig. 4) was built in AD 62 or earlier. The second (East-West Way, Fig. 3) is dated by dendrochronology to the period from AD 97/98 to AD 145/146. Phase 3 is defined by large buildings closely associated to the EastWest Way (buildings 2 and 3 but also thermae) dated to the first half of the 2nd century AD. These buildings allow us to attribute a terminus ante quem of winter AD 145/146 to the Roman roads, by the dendrochronological dating of several piles. The thermae complex represents the last period of occupation, which occurred in the second half of the 2nd century AD.

\section{Excavation and field study measurement}

Planimetric surveys at scales of $1 / 20$ and $1 / 50$ were performed in order to document the spatial extent of stratigraphic units. The archaeological context provides accurate chronological information and leads to better interpretation of anthropogenic deposits. During several excavation surveys, field observations were made on several cross-sections and trenches. Stratigraphic description was performed at the $1 / 20$ scale, in order to study the rapid facies variations in archaeological levels, in this alluvial sedimentary environment. Therefore the sequence of palaeochannel fill deposits was studied in relation with the Gallo-Roman settlements. In this way, in spite of considerable lateral variation, facies were spatially tracked at the scale of the excavation, and correlations became possible. During field study, facies were described using sediment type, grain size, geometry, bioturbation features,

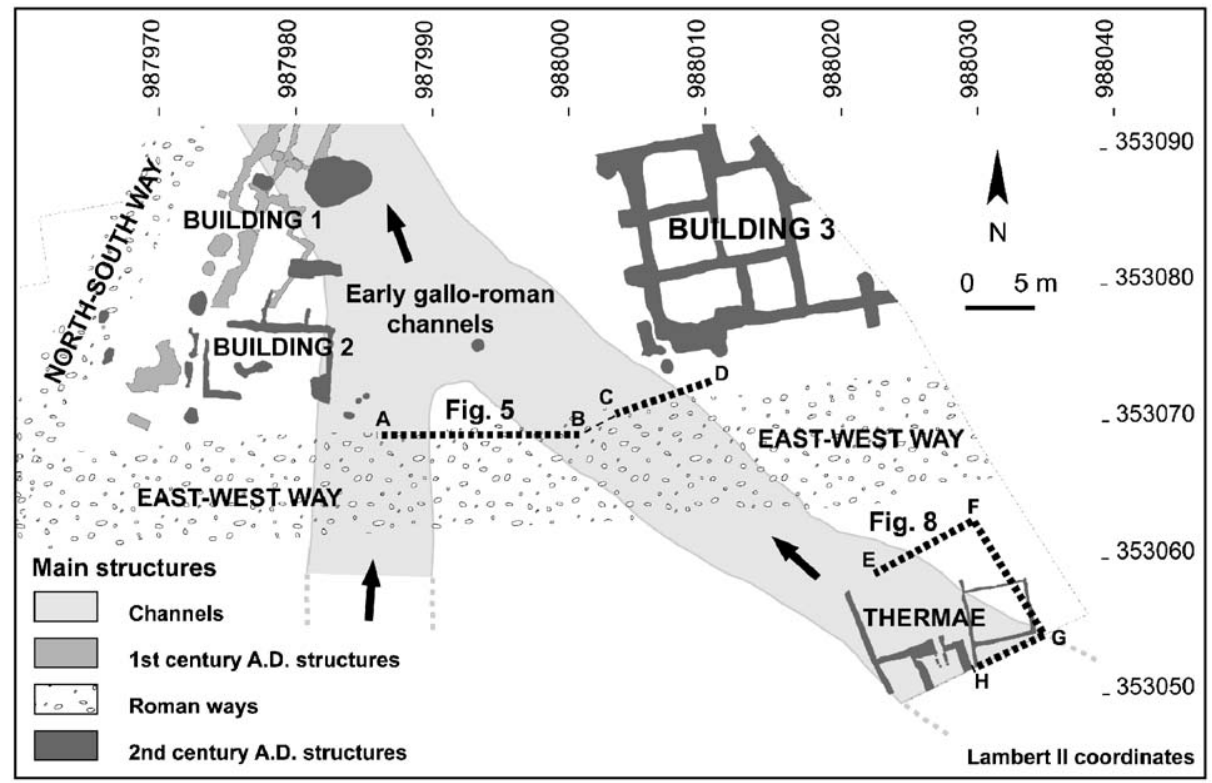

Fig. 4. Map of the main excavated structures dated from 1st to 3rd century. Spatial coordinates are Lambert II extended. 
pedogenesis and basal contact, but also with reference to their relationships with archaeological structures.

The great density of samples taken as columns or cores of sediments allowed the construction of reference sequences. Microgranulometry analysis was performed using a Coulter LS 130. The detector range is from $0.4 \mu \mathrm{m}$ to about $900 \mu \mathrm{m}$ with the Fraunhofer optical model. We analysed 75 samples to quantify the respective proportions of clays, silts and sands within sediments (Passega, 1957; Rivière, 1977). The micromorphological study of soft sediment was performed by analysing 14 thin sections. These investigations were carried out in order to detect elementary sedimentary structures, possible bioturbation tracks (e.g. burrows and roots), fossil organic remains (e.g. gastropods and plants), trampled zones, and load structures. Over 200 wood samples were analysed using dendrochronology (Petit et al., 2005).

\section{Results}

\subsection{Facies and geometric description}

Anthropogenic as well as alluvial sediments were recognised and nine major facies types were described (Figs. 5-8). From facies interpretation, it is possible to infer different depositional processes, referred to as natural channel/floodplain and anthropogenic deposits.

\subsubsection{Fluvial facies}

4.1.1.1. Gravel and pebbles (facies g). Facies g corresponds to imbricated gravels and pebbles (main grain size $6-10 \mathrm{~cm}$ ) in the substratum. It corresponds to mid-channel bars formed after the period of incision of the floodplain terrace during the Lateglacial Period (Blanalt et al., 1974; Théobald et al., 1978). After its formation, this bar stopped migrating and became an island separating two small channels. This facies has been recognised on the island situated between the two palaeochannels (Fig. 5).

\subsubsection{Silts and clays (facies a)}

Description. The lower part of the observed channel-fill sequence (facies a) is older than the excavated archaeological structures. This facies is a homogenous light yellow or blue hydromorphic mud, onlapping and filling the broad channel, as observed in aerial photographs. It is a fining-upward layer from silty-sand to sandy-silt at the bottom, to clayey-silts at the top of the fill (Fig. 5). Rare root tubules are present (Fig. 6). At the top of this layer, the clayey-silty fraction largely dominates, forming up to $95 \%$ of the sediment. Moreover, the major mode is close to $10 \mu \mathrm{m}$ with two secondary modes; the size parameters indicate a wide range of grain size and a poor sorting (Fig. $6 b$ ). This detrital deposit, up to $2 \mathrm{~m}$ thick, exhibits neither sedimentary structures nor any bedding. These fine silt deposits were successively cut across by a new, shallower (less than $2 \mathrm{~m}$ ), narrower (about $10 \mathrm{~m}$ ), SSE-NNWoriented palaeochannel, cutting across the Holocene channel fill (Fig. 5).

Interpretation: gradual channel infilling: The homogenous silty-clay sediment (facies a), represents a period of decantation as the main sedimentation mode in the channel, i.e. uniform suspension on a $\mathrm{C} / \mathrm{M}$ diagram. This is the first step in the filling of the palaeochannels in this part of the Rhine floodplain. The incision of the top of this layer and the superimposed root tracks give evidence of one erosional phase, i.e. a short period of channel reactivation, followed by the development of vegetation within an aquatic environment.

\subsubsection{Organic-rich silts and fine sands (facies b)}

Description. The first occurrence of facies $b$ is well observed due to colour and texture differences when compared to facies a. This facies occurs at two distinct levels. The lower occurrence is found over the basal erosive surface of the palaeochannel, interlayered with facies $\mathrm{d}$ and e. It constitutes a channel deposit of the Early GalloRoman, due to its contemporaneous relationship to
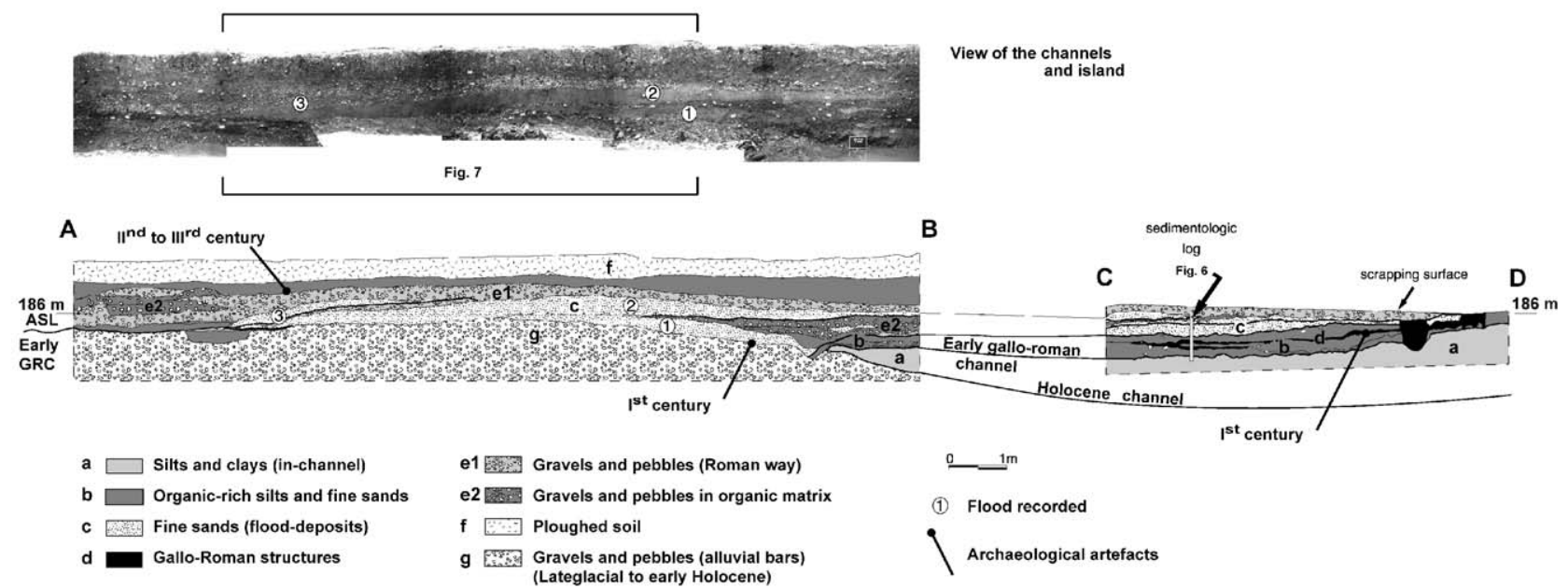

Fig. 5. Stratigraphic cross-section (A-B, C-D) and photograph of the Early Gallo-Roman Channel (early GRC) and the island of the main part of the 1st-3rd century Gallo-Roman town. Three flood deposits (facies c 1, 2, and 3) are interlayered with anthropogenic deposits (facies d and e). 


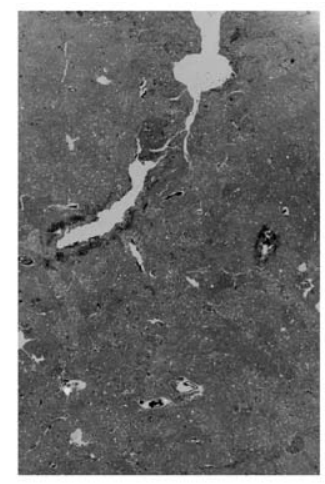

Clays and fine silts deposit (channel fill deposit)

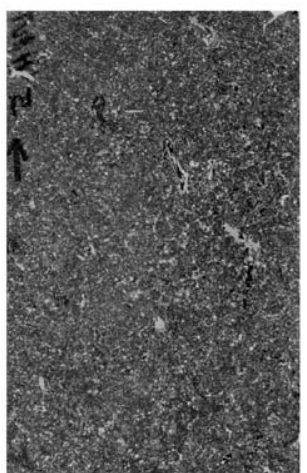

Organic rich silts and very fine sands (channel fill deposit)

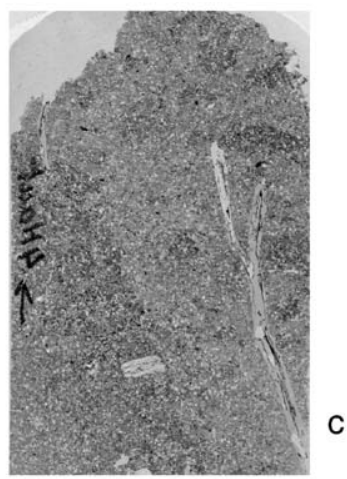

Fine sand

(flood deposit)

(A)

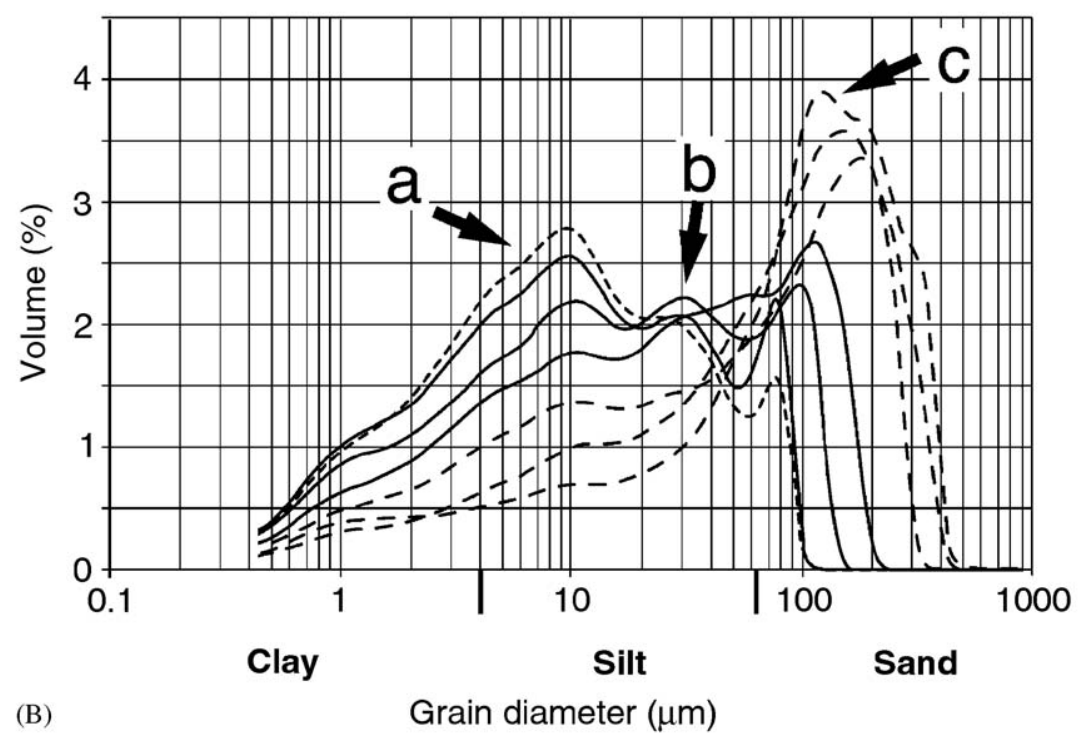

Fig. 6. (A) Micromorphological thin sections of the three alluvial facies. Facies a shows burrows and root tracks. Facies b is composed of many organic matter allochems. Facies c seals vertical vegetal remains (stems). (B) Microgranulometry results of facies a, b and c. In facies a, the clayey-silty fraction largely dominates, with a wide range of grain sizes and poor sorting. The major mode is close to $10 \mu \mathrm{m}$. In facies b a three-mode distribution is shown. Facies c presents a well-sorted grain-size distribution with a single mode at about $150 \mu \mathrm{m}$.

archaeological structures dated to the 1st century AD. The same facies extends over the whole study area: it has also been recognised in deposits from the 4th century to the Modern Period. Facies b corresponds to organic-rich fine silty-clayey sandy deposits. A three-mode distribution is shown in Fig. 6. Many allochems of organic origin are observed. No evidence of bioturbation nor of pedogenesis is observed but it is clear that the root tracks observed in facies a are caused by vegetation growing within the Early Gallo-Roman channel during the deposition of facies $b$.

Interpretation: abandoned channel deposits: Compared to facies a, the sandy fraction in this sediment reaches about $25 \%$ (Table 1). This evolution towards coarser facies in $b$ is interpreted on a $\mathrm{C} / \mathrm{M}$ diagram (Passega, 1957) as a higher contribution of graded suspension. The high content in organic matter and also the vegetation growing within the channel (facies b) are interpreted as inherited from a marsh environment. Therefore, this part of the floodplain was disconnected from river dynamics except during floods. This depositional episode is contemporaneous with the first observed human settlement, and is dated by dendrochronology at about AD 20 or earlier. It constitutes the Early Gallo-Roman channel.

\subsubsection{Fine sands (facies $c$ )}

Description. The basal boundary surface of facies $\mathrm{c}$ is erosional in character in every excavation (Figs. 5 and 7). Facies $\mathrm{c}$ is a fine sandy sterile layer which is present over the whole excavation surface. Layers of facies $c$ are about $10-20 \mathrm{~cm}$ thick and show a continuous sheet shape. They are referred as to 1, 2, 3 and 4 in Figs. 5 and 8. The first was deposited on facies $d$ on the island, and on facies $b$ in the 
palaeochannels. The remaining three facies c deposits are interfingered within coarser levels (facies e1 and e2) and their geometric relationship is prograding in character. Closer observation of vertical vegetal remains (stems) in thin sections attests the single-event deposition of sediments, sealing the previous levels at one and the same time (Fig. 6). This facies presents a well-sorted grain-size distribution, with a single mode at about $150 \mu \mathrm{m}$. However, a fining-upward sorting is observed and measured by

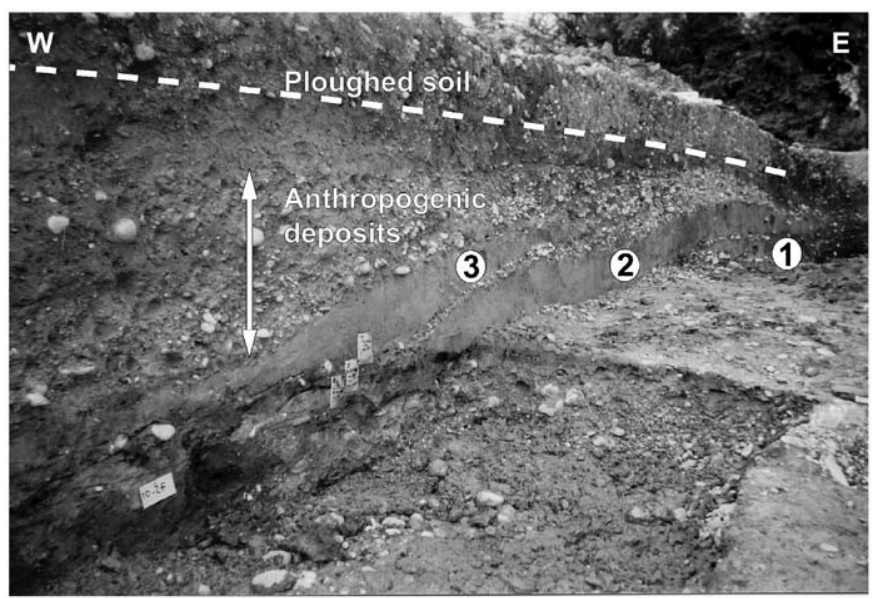

Fig. 7. Oblique field photograph of the cross-section A-B showing lateral extension of flood deposits and thickness variation of anthropogenic deposits. Small boxes are $5 \mathrm{~cm}$ long. decreasing median values, from $82 \mu \mathrm{m}$ at base to $46 \mu \mathrm{m}$ at the top, as indicated in Table 1.

These layers are commonly affected by an upper erosional truncation observed more frequently in the two palaeochannel thalwegs than in the borders (Fig. 7). Where the third layer of facies $\mathrm{c}$ is preserved in the western palaeochannel, it is enriched in organic matter. In Figs. 5, 7 and 8 , the geometry of facies $\mathrm{c}$ deposits is shown, overlapping facies $\mathrm{b}$ or facies el deposits. The truncation is also well observed at the interface between facies $\mathrm{c}$ and facies e1 layers, showing a basal erosion surface as well as an upper erosion surface for facies c. It is clearly identified that erosional processes were more effective in the channels than on the island, leaving only eroded scraps, even if facies $\mathrm{c}$ deposits originally had a sheet or a lens shape.

Interpretation: overbank deposits: The homogenous unimodal well-sorted fine sands which are characterised by fining-upward sorting (facies c) indicate a deposition under decelerating flow conditions, i.e. graded suspension on a $\mathrm{C} / \mathrm{M}$ diagram (Table 1). Moreover, they show a basal erosional surface and a broad spatial distribution on islands as well as in palaeochannels. These indicate the event origin of these deposits, i.e. floods, according to the environmental context. Each flood deposit is interlayered with anthropogenic levels, allowing accurate dating of the events. The preservation of these deposits is better on the islands than in the palaeochannels, possibly due to water flow erosion at the end of the floods. These incisions have

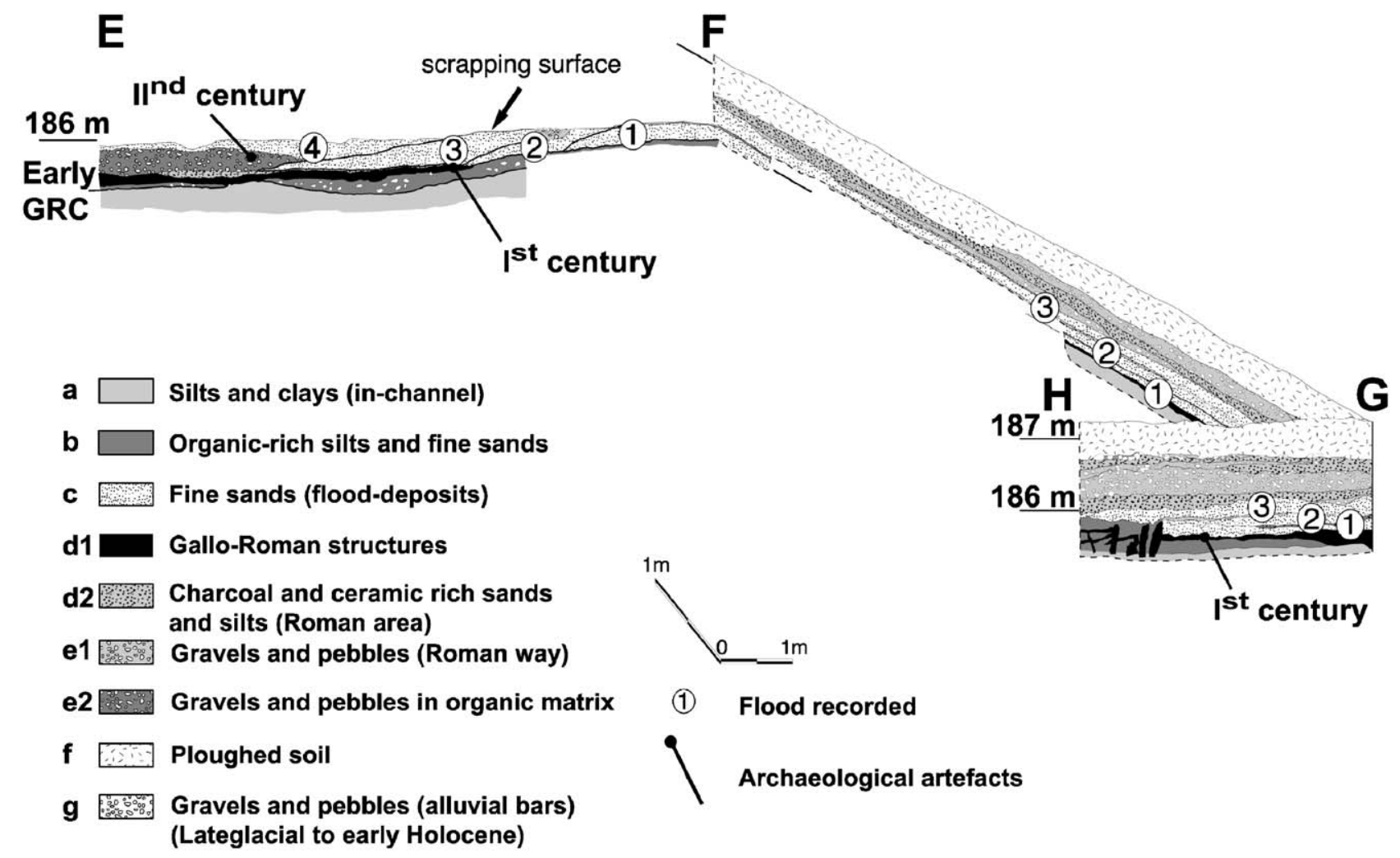

Fig. 8. Stratigraphic cross-section (E-F, F-G, G-H) of the Early Gallo-Roman Channel (early GRC) in the southern part of the study area. Four flood deposits (facies c 1, 2, 3 and 4) are interlayered with anthropogenic deposits (facies d and e). 


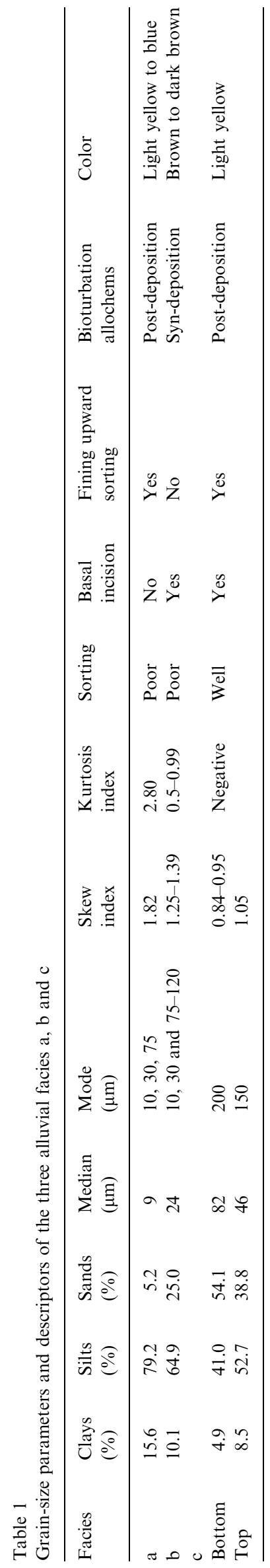

been observed at the top of each flood deposit. The position near the concave bank of a main meandering palaeochannel (Fig. 3) allows us to consider these deposits as crevasse splay deposits (Leopold et al., 1957; Reineck and Singh, 1980; Bridge, 2004). We identified four separate flood deposits, all very similar. Such deposition in this location, comparable to well-known historical floods, allows us to consider that almost all the Rhine alluvial plain in the vicinity of the Gallo-Roman site of Oedenburg was inundated (Fig. 9). An organic marsh (facies b) typical for the Rhine "Ried", developed after the Roman Period. The "Ried" marsh persisted until the 19th century. However, although such a marshy environment is likely to preserve flood deposits, no events were recorded during this period, yet historical documentation provides evidence of several floods (Fig. 7). This deficiency is probably due to ploughing and biological activity during the 20th century.

\subsubsection{Anthropogenic deposits}

4.1.2.1. Organic-rich anthropogenic deposits (d1 and $d 2$ )

Description. Facies d1 corresponds to wood-rich layers oriented in the same direction (woven brushwood deposits), and is considered in the archaeological context as a circulation surface associated to several structures dated from the 1 st century (building 1). Facies d2 is a "throw-out deposit", i.e. a ceramic-, tegulae-, mortar- and charcoalrich sediment indicating the proximity of human occupation.

Interpretation: Facies $\mathrm{d} 1$ and $\mathrm{d} 2$ may be interpreted as anthropogenic deposits because they are associated with excavated structures (Fig. 4). Facies d1 corresponds to a wooden installation, whereas facies $\mathrm{d} 2$ is a rubbish deposit.

\subsubsection{Building materials (facies e1 and e2)}

Description. Facies el corresponds to sandy gravel and pebble anthropogenic deposits. Laterally, the facies grades into an organic-rich matrix in the channel areas (facies e2). These facies stratasets are always associated with other Roman structures (buildings 1, 2 and 3). These layers are interlayered with the finer levels of facies $\mathrm{c}$.

Interpretation: These archaeological structures are Roman road levels or pathways and wall foundations; they are thicker in the palaeochannel than on the island surface.

4.1.2.3. Ploughed soil (facies f). Ploughed soil from modern agricultural activities is characterised by disorganised anthropogenic remains in a brown organic-rich sandy-silt matrix (Fig. 6).

\section{Discussion}

\subsection{Flood event chronology on the site}

The four recorded flooding events occurred during a short period of time, between AD 20 and AD 145/146, as indicated by dendrochronological dating (Petit et al., 


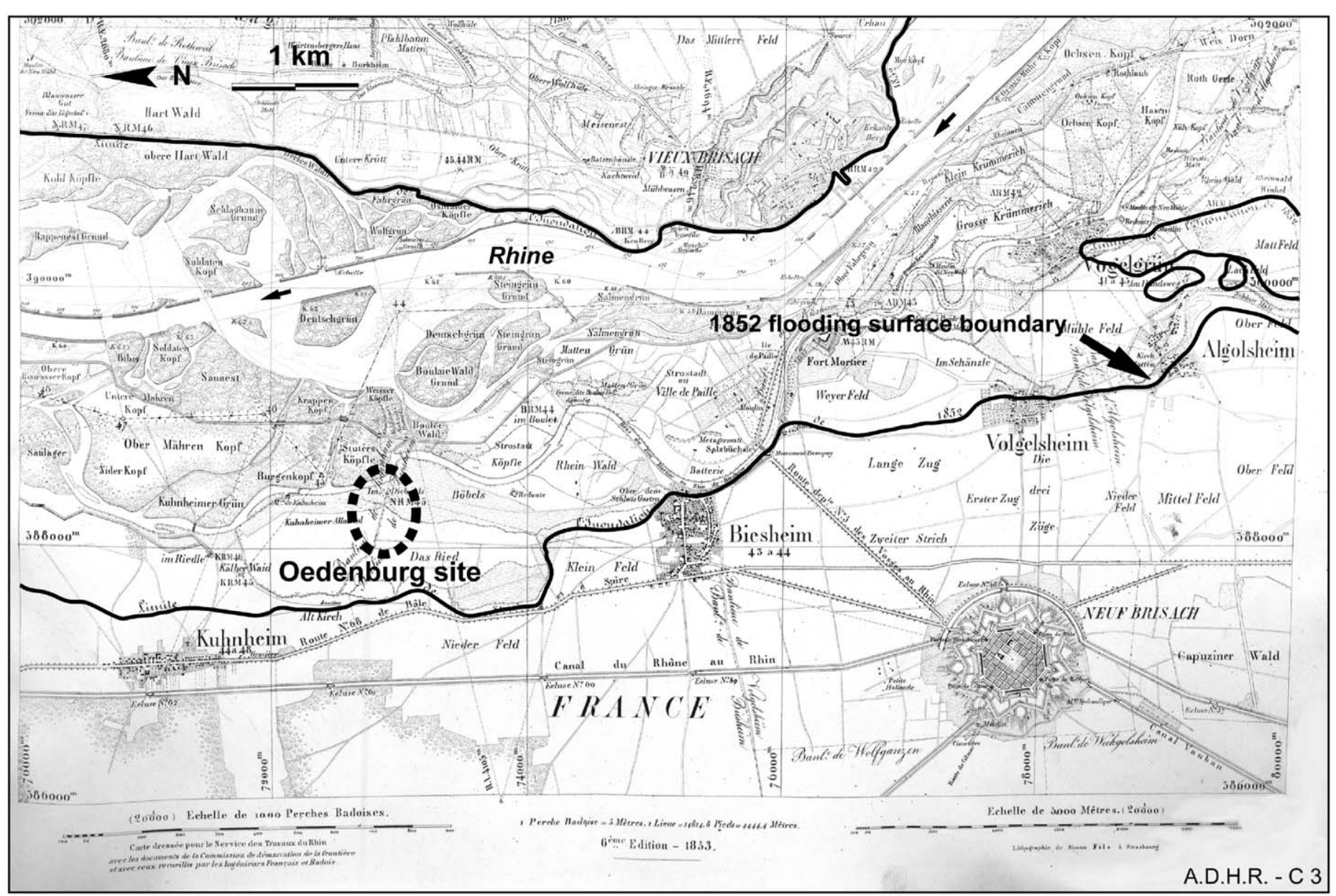

Fig. 9. Ancient map of the Oedenburg area, showing the spatial extent of the 1852 flood event. After a map dated 1853 (Archives Départementales du Haut-Rhin, France). Note the location of "New-Kunheim", situated outside the floodplain.

2005). Few historic floods of comparable extent are known in this lateral part of the Rhine floodplain. For example, by studying ancient maps, we know that the flood event of 1852 , considered to have a centennial return-period, was of similar extent (Fig. 9). This very notable, well-documented historical event is known to be as severe as the exceptional floods of 1641 (6.54 m, under Basel Bridge), and of 1876 $\left(5000 \mathrm{~m}^{3} / \mathrm{s}\right.$, Basel [the greatest flood known in Basel]; $5700 \mathrm{~m}^{3} / \mathrm{s}$, Strasbourg) (Champion, 1863; Criqui, 1981; Maire and Sanchez-Perez, 1992; Descombes, 1995; Conrad, 1999). Even if site abandonment after floods (Brown, 1997) is rare, the town of Kunheim (Figs. 2 and 9) was abandoned after being partially destroyed by the 1763 flood event.

Therefore, for an alluvial morphology similar to that of the Modern Period, this part of the Rhine floodplain must be considered to have been inundated only during centennial-scale flood events. Even if the flood sensitivity and frequency in this area has changed since Antiquity, it is probable that the floods recorded in Oedenburg:

(1) were of considerable size, because of the lack of other flood deposits during the period before and after Roman settlement.
(2) seem to be clustered within a short time interval of about 125 years: from AD 20-AD 145/146.

\subsection{Rhine River}

The archaeological data highlighting ancient hydrological variations of the Rhine in the Alsace floodplain are very scarce. Nevertheless, Rhine floods are also known at Ehl (Bas-Rhin) around AD 50-60, 80 and 97-160 (Hatt, 1954, 1966a, b; Provost, 1984; Vogt, 1988). The four flood events recorded in the Oedenburg Gallo-Roman site happened during this time interval, from AD 20 to AD 145/146.

In the same catchment area, in Lake Constance, flood events have been identified in 4100, 3300 and 2600 cal.year BP. Such events were only observed during glacial advances in the Alps. For later periods, some other coarse laminae that we interpret as flood deposits were recognised as being deposited in around AD 100-200 (Wessels, 1998). According to Starkel (2002), 'the fragmentary records of events in the fluvial system can coincide with smoothed variations of the lake level'. Therefore, it is possible to consider that the four floods recorded in the Oedenburg Gallo-Roman site are also recorded in the lacustrine deposits of Lake Constance. 


\subsection{Alpine region}

In other Alpine catchments, numerous flood events and lake-level fluctuations have been recognised during Antiquity. In the whole Rhône catchment area, several floods may be associated with a humid period during the first two centuries AD (Provansal et al., 1999). In the Rhône delta, the period between $100 \mathrm{BC}$ and AD 200 corresponds to a higher sedimentation rate of alluvial origin (Arnaud-Fassetta and Landuré, 2003). However, this 1st and 2nd century AD alluvial phase in the Rhône catchment area is interpreted as being amplified by anthropogenic forcing (Bruneton et al., 2001; ArnaudFassetta, 2002; Salvador et al., 2002; Berger et al., 2003, 2004). Moreover, the short period when the four centennial-scale floods in Oedenburg occurred is contemporaneous with the 'Petit Maclu 1' trangressive phase recorded in Jura lakes (Petit Maclu, Léman, Le Bourget, de Pluvis and Zurich Lakes). It began in AD 18, and probably ended before the start of the third century (Magny, 1993, 2004).

Nevertheless, the flood events that occurred during a long period of favourable climatic conditions and immediately following the first Iron Age degradation period (3500-2500 BP) do not seem to be identified at a global scale (Mayewski et al., 2004).

\section{Conclusion}

The Gallo-Roman site of Oedenburg provides a very good record of Rhine flood deposits, and allows the study of discrete events as well as continuous alluvial changes during the whole settlement period: i.e. channel abandonment and marsh development, or, conversely, channel activity. The landscape at the time of the first Roman settlers was composed of two wide meandering channels running between gravelly islands, and several little channels and marshy zones. These palaeochannels were filled with organic-rich silty-sands, then occupied from AD 20 to the second century. During this period, between AD 20 and AD 145/146, four floods occurred in the Rhine floodplain, and were recorded on the archaeological site. Dendrochronological dating and archaeological excavation framework allow us to define the chronology and spatial distribution of the flood deposits with great accuracy. Moreover, archaeological structures and artefacts deposits testify for an immediate re-occupation of this zone after each flood event.

This suggests that the hydrological risk in the Rhine floodplain did not interfere significantly with Roman settlement planning, but also that any civil engineering, if existent, was not efficient enough to protect the zone from flood risk. These floods are similar in extent to those that occurred in 1641, 1852 and 1876. Even if only a small part of the catchment is observed through archaeological excavation, it is possible to assess the rank of four major floods in this area, situated far from the main active braided zone of the Rhine River. Flood frequency is difficult to assess but appears to have no significance in human history in this part of the Rhine floodplain.

\section{Acknowledgements}

This research was supported by (1) the FrenchGerman-Swiss 'Oedenburg Program', (2) the UMR-CNRS 5561 'Biogéosciences', Centre des Sciences de la Terre, Université de Bourgogne, and (3) the Ecole Doctorale Buffon. Their support allowed us to present our results at the 32nd International Geological Congress, Florence, Italy: Geoarcheology for climatic changes and catastrophic events in human history. All sedimentological analyses were carried out at the Université de Bourgogne. All dendrochronological analyses were carried out by Olivier Girarclos (CEDRE, Besançon, France). The authors would also like to thank Carmela Chateau-Smith for her helpful contribution to this work.

\section{References}

Arnaud-Fassetta, G., 2002. Geomorphological records of a 'flooddominated regime' in the Rhône Delta (France) between the 1st century $\mathrm{BC}$ and the $2 \mathrm{nd}$ century $\mathrm{AD}$. What correlations with the catchment paleohydrology? Geodinamica Acta 15 (2), 79-92.

Arnaud-Fassetta, G., Landuré, C., 2003. Hydroclimatic hazards, vulnerability of societies and fluvial risk in the Rhone Delta (Mediterranean France) from the Greek period to the early middle ages. In: Fouache, E. (Ed.), The Mediterranean World Environment and History. Proceedings of the International Conference on Environmental Dynamics and History in Mediterranean Areas, Paris, 24-26 April 2002. Elsevier, Paris, pp. 51-76.

Baize, D., Girard, M.-C., Arrouays, D., Aubert, G., Aubrun, A., Aurousseau, P., Beaudou, A., Bornand, M., Boulaine, J., Bresson, L.M., Brethes, A., Chrétien, J., Favrot, J.-C., Jabiol, B., Jamagne, M., Kaloga, B., Laplace-Dolonde, A., Loyer, J.-Y., Luspascu, G., Marius, C., Ninov, N., Podwojevski, P., Pouget, M., Quantin, P., Righi, D., Rossignol, J.-P., Ruellan, A., Van Vliet, B., Vizier, J.-F., 1995. Référentiel pédologique. INRA, Paris 332pp.

Berger, J.-F., Fiches, J.-L., Gazenbeek, M., 2003. Origin of fluvial fluctuations of the river Vidourle and their effect on the organisation and evolution of the site of Ambrussum (Herault, France) between the Iron Age and Late Antiquity. In: Fouache, E. (Ed.), The Mediterranean World Environment and History. Proceedings of the International Conference on Environmental Dynamics and History in Mediterranean Areas, Paris, 24-26 April 2002. Elsevier, Paris, pp. $77-108$.

Berger, J.-F., Fiches, J.-L., Gazenbeek, M., 2004. La gestion du risque fluvial à Ambrussum durant l'Antiquité par les riverains du Vidourle. In: Burnouf, J., Leveau, P. (Eds.), Fleuves et marais, une histoire au croisement de la nature et de la culture. Comité des Travaux Historiques et Scientifiques, Paris, pp. 419-435.

Blanalt, J.-G., Eller, J.-P., Fluck, P., Geffroy, J., Hillermann, G., Jehl, M., Monnet, C., Schreiner, J., Eckerle, A., Sittler, C., Schwoerer, P., Tricart, J., Hirth, C., Vogt, M., Weil, R., Siat, A., 1974. Notice explicative de la carte géologique de la France à $1 / 50000$, Feuille Colmar-Artolsheim.

Bridge, J.S., 2004. Rivers and Floodplains: Forms, Processes, and Sedimentary Record. Blackwell Publishing, Oxford 491pp. 
Bridge, J.S., Smith, N.D., Trent, F., Gabel, S.L., Bernstein, P., 1986. Sedimentology and morphology of the low-sinuosity Calamus River, Nebraska Sandhills. Sedimentology 36, 851-870.

Brown, A.G., 1997. Alluvial Geoarchaeology. Floodplain Archaeology and Environmental Change. Collection Cambridge Manuals in Archaeology. Cambridge University Press, Cambridge 377pp.

Bruneton, H., Arnaud-Fassetta, G., Provansal, M., Sistach, D., 2001. Geomorphological evidence for fluvial change during the Roman Period in the lower Rhone valley (southern France). Catena 45 (4), 287-312.

Carbeiner, R., 1997. Le Grand Ried d'Alsace. Bulletin de la Société Industrielle de Mulhouse 734, 15-44.

Champion, M., 1863. Les inondations en France depuis le VI ${ }^{\text {ème }}$ siècle jusqu'à nos jours, T. 5: Bassin du Rhin. Dunod, Paris 283pp.

Church, M., 1978. Paleohydrological reconstruction from a Holocene Valley fill. In: Miall, A.D. (Ed.), Fluvial Sedimentology, Memory of the Canadian Society of Petroleum Geologists, Calgary, vol. 5, pp. 743-772.

Conrad, O., 1999. Fléaux et calamités naturelles au siècle dernier dans le Haut-Rhin. Annuaire de la Société d'Histoire de la Hardt et du Ried $12,93-114$.

Criqui, G., 1981. Le régime hydraulique, les crues et les inondations du Rhin. In: Ayçoberry, P., Ferro, M. (Eds.), Une histoire du Rhin. Ramsay, Paris, pp. 317-336.

Decoville-Faller, M., 1961. Les transformations du réseau hydrographique réalisées depuis un siècle dans la région de Neuf-Brisach. Regio Basiliensis 2, 113-134.

Descombes, R., 1995. L'eau dans la ville. Des métiers et des hommes. Hirlé, Strasbourg 351pp.

Eisenmenger, G., 1907. Etudes sur l'évolution du Rhin et du système hydrographique rhénan. Bonvalot-Jouve, Paris 512pp.

Hatt, J.-J., 1954. Les fouilles de Strasbourg en 1953 et 1954, découverte d'un dépotoir de céramiques. Gallia 12 (2), 323-339.

Hatt, J.-J., 1966a. Ehl (Ellelum?). Gallia 24 (2), 313-319.

Hatt, J.-J., 1966b. Le Rhin dans l'Histoire. L'Antiquité. Connaissance du Rhin, Saisons d'Alsace, Strasbourg 153pp.

Klein, J.-P., Carbeiner, R., Steimer, F., Trendel, J.-M., 1992. Les réserves naturelles des forêts alluviales rhénanes d'Erstein et d'Offendorf: Un patrimoine biologique européen. Bulletin de la Société Industrielle de Mulhouse 824, 21-58.

Lefoulon, R., 1959. L'aménagement du Rhin sur le tronçon entre Bâle et Strasbourg. La Houille Blanche 2, 203-306.

Leopold, L.B., Wolmann, M.G., Miller, J.P., 1957. Fluvial Processes in Geomorphology. Freeman, San Francisco 522pp.

Mäckel, R., Schneider, R., Friedmann, A., Seidel, J., 2002. Environmental changes and human impact on the relief development in the upper Rhine valley and Black Forest (South-West-Germany) during the Holocene. Zeitschrift für Geomorphologie, Suppl. Bd. 128, $31-45$.

Mäckel, R., Schneider, R., Seidel, J., 2003. Anthropogenic impact on the landscape of southern Badenia (Germany) during the Holocenedocumented by Colluvial and Alluvial sediments. Archaeometry 45 (3), 487-501.

Magny, M., 1993. Solar influences on holocene climatic changes illustrated by correlations between past lake-level fluctuations and atmospheric ${ }^{14} \mathrm{C}$ record. Quaternary Research 40, 1-9.

Magny, M., 2004. Holocene climatic variability as reflected by midEuropean lake-level fluctuation and its probable impact on prehistoric humain settlement. Quaternary International 113, 65-80.

Maire, G., Sanchez-Perez, J.-M., 1992. Influence des aménagements hydrauliques du Rhin sur le fonctionnement hydrologique des forêts riveraines d'Alsace: L'exemple du secteur de l'île de Rhinau. Bulletin de la Société Industrielle de Mulhouse 824, 9-19.

Marchal, M., Delmas, G., 1959. L'aménagement du Rhin à courant libre de Bâle à Lauterbourg. La Houille Blanche 2, 177-202.

Mayewski, P.A., Rohling, E.E., Stager, J.C., Karlén, W., Maasch, K.A., Meeker, L.D., Meyerson, E.A., Gasse, F., van Kreveld, S., Holmgren, K., Lee-Thorp, J., Rosqvist, G., Rack, F., Staubwasser, M., Schneider,
R.R., Steig, E.J., 2004. Holocene climate variability. Quaternary Research 62, 243-255.

Miall, A. (Ed.), 1996. The Geology of Fluvial Deposits. Springer, Berlin 596pp.

Nuber, H.U., Reddé, M., Jacomet, S., Joly, M., Popovitch, L., Schibler, J., Seitz, G., Fort, B., Matter, G., Pellissier, J., Petit, C., Viroulet, B., Wolf, J.-J., 2002. Le site militaire romain d'Oedenburg (BiesheimKunheim, Haut-Rhin, France). Premiers résultats. Germania 80, 169-242.

Passega, R., 1957. Texture as a characteristic of clastic deposition. Bulletin of the American Association of Petroleum Geologists 41, 1952-1984.

Petit, C., Girarclos, O., Ollive, V., Reddé, M., 2006. Milieux humides et aménagements anthropiques dans la plaine du Rhin: Le site romain d'Oedenburg (Haut-Rhin). VIIème Colloque AGER, Silva et Saltus en Gaule romaine. Dynamique et gestion des forêts et des zones rurales marginales, in press.

Provansal, M., Berger, J.F., Bravard, J.-P., Salvador, P.G., ArnaudFassetta, G., Bruneton, H., Verot-Bourrely, A., 1999. Le régime du Rhône dans l'Antiquité et au Haut Moyen-Age. Gallia 56, 13-32.

Provost, M., 1984. L'homme et les fluctuations climatiques en Gaule dans la deuxième moitié du $2^{\text {ème }}$ siècle après Jésus-Christ. Revue Archéologique 1, 71-78.

Reddé, M., Nuber, H.U., Jacomet, S., Schibler, J., Schucany, C., Schwartz, P.-A., Joly, M., Petit, C., Plouin, S., Seitz, G., Viroulet, B., Wolf, J.-J., Ginella, F., Vandorpe, P., Gissinger, B., Hüster Plogmann, H., Ollive, V., Pellissier, J., Schlumbaum, A., Wick, L., 2005. Oedenburg. Une agglomération d'époque romaine sur le Rhin supérieur. Gallia 62, 215-277.

Reineck, H.E., Singh, I.B., 1980. Depositional Sedimentary Environments. Springer, Berlin 551pp.

Rivière, A., 1977. Méthodes granulométriques: Techniques et Interprétations. Masson, Paris 182pp.

Salvador, P.G., Vérot-Bourrély, A., Bravard, J.-P., Franc, O., Macé, S., 2002. Les crues du Rhône à l'époque gallo-romaine dans la région lyonnaise. In: Bravard, J.-P., Magny, M. (Eds.), Histoire des rivières et des lacs de Lascaux à nos jours. Errance, Paris, pp. 215-221.

Schäfer, W., 1973. Der Oberrhein, sterbende Landschaft? Natur und Museum 103 (1), 1-29.

Schumm, S.A., 1981. Evolution and response of the fluvial system, sedimentologic implications. SEPM, Special Publication 31, 19-29.

Sell, Y., Berchtold, J.-P., Callot, H., Hoff, M., Gall, J.-C., Walter, J.-M., 1998. L'Alsace et les Vosges. Géologie, milieux naturels, flore et faune, Delachaux et Niestlé, Paris $354 \mathrm{pp}$.

Starkel, L., 2002. Change in the frequency of extreme events as the indicator of climatic change in the Holocene (in fluvial systems). Quaternary International 91, 25-32.

Striedter, K., 1988. Le Rhin en Alsace du Nord au Subboréal. Genèse d'une terrasse fluviatile holocène et son importance pour la mise en valeur de la vallée. Bulletin de l'Association Française pour l'Etude du Quaternaire 1, 5-10.

Théobald, N., Ménillet, F., Lougnon, J., Bonnet, C., Fluck, P., 1978. Notice explicative de la carte géologique de la France à 1/50000, Feuille Neuf-Brisach.

Thorne, C.R., Russel, A.P.G., Alam, M.K., 1993. Planform pattern and channel evolution of the Bramaputra River, Bangladesh. In: Best, J.L., Bristow, C.S. (Eds.), Braided Rivers. Geological Society of London Special Publication 75, pp. 257-276.

Tricart, J., Bravard, J.-P., 1991. Le cours périalpin du Rhin, du Rhône et du Danube: aménagement fluvial et dérives de l'environnement. Annales de Géographie 561-562, 668-713.

Tulla, J.G. von, 1825. über die Rektifikation des Rheins, von seinem Austritt aus der Schweiz bis zu seinem Eintritt in das Grossherzogtum Hessen, Karlsruhe, 60pp.

Tulla, J.G. von, 1827. Sur la rectification du cours du Rhin, depuis son débouché de la Suisse jusqu'à son entrée dans le grand duché de HesseDarmstadt. Journal de la société des sciences, agriculture et arts de Strasbourg 5-63. 
Vogt, H., 1988. Le site de Strasbourg, Aux origines de l'Alsace. Les musées de la Ville de Strasbourg, Strasbourg, pp. 10-12.

Wessels, M., 1998. Natural environmental changes indicated by Late Glacial and Holocene sediments from Lake Constance, Germany. Palaeogeography, Palaeoclimatology, Palaeoecology 140, 421-432.
Williams, P.F., Rust, B.R., 1969. The sedimentology of a braided river. Journal of Sedimentary Petrology 39, 649-679.

Zehner, M., 1998. Carte Archéologique de la Gaule. Le Haut-Rhin, 375pp. 